\title{
Recent Publications
}

\section{BOOK REVIEWS}

Non-Book Materials Cataloging Rules; Integrated Code of Practice and Draft Revision of the Anglo-American Cataloging Rules British Text Part III, prepared by the Library Association Media Cataloging Rules Committee. London: National Council for Educational Technology with the Library Association (Available from Councils and Education Press), 1973. (NCET Working Paper No. 11)

The initiative for the establishment of the Media Cataloging Rules Committee came from a meeting called by NCET in 1970, at which representatives of a number of associations recommended the setting up of a centrally held machine-readable file of records related to available media resources. Among the needs of such a file would be standardization of inputs; and a major recommendation of the meeting was that a standard form of description of the various types of materials was a first requirement for further development.

At the same time, the Library Association was aware of the inadequacy of the Anglo-American Cataloging Rules (AACR) of 1967 with respect to non-book materials. The British Text was particularly vulnerable to criticism in that it omitted much of the material drafted by the American authors (ALA, Library of Congress, Canadian Library Association) as Part 3, Non-Book Materials. Other standards of non-book materials cataloging also were published during this period-the AECT's Standards for Cataloging Non-print Materials and the 1970 draft of Jean Riddle Weihs' Non-book Materials: The Organisation of Integrated Collections. The interest of the NCET and Library Association in the establishment of authoritative cataloging standards for non- book materials resulted in the setting up of the Media Cataloging Rules Committee by the Library Association, with substantial financial support from the NCET. As work progressed, information and ideas were exchanged with Jean Riddle Weihs and her colleagues in Canada; and the committee was represented by its chairman at the Dallas (June 1971) and Chicago (June 1972) American Library Association meetings. At the Chicago meeting, preliminary drafts of the British "general rules" were examined in some detail and recommended in principle as a basis for the revision of the AACR.

This publication has been designed first and foremost as a self-contained code of practice in its own right. However, as the rules themselves indicate, occasional reference to the full text of the AACR is likely to be needed in the solution of more abstruse problems common to the cataloging of all categories of materials, i.e., the establishment of a particular form of heading. Often it was convenient to adopt or refer to existing rules in AACR rather than to invent new ways of saying the same thing. To facilitate eventual incorporation into the $A A C R$, an attempt has been made to conform to the general structure and notational style of individual rules in the AACR.

In offering the rules as a draft standard for the revision of the AACR, the committee makes one very important recommendation: that the present AACR chapters 10 (Manuscripts), 11 (Maps, etc.), and 13 (Music) are not embraced by this draft, that these chapters should preferably be taken out of the present Part III and regrouped in closer relationship with parts I and II (dealing with written and printed materials) with which they have a closer affinity than with the rest of Part III. The 
present draft is seen as a replacement for the remaining AACR chapters in Part III: 12 (Motion Pictures and Filmstrips), 14 (Phonorecords), and 15 (Pictures, Designs, etc.).

The format of the rules is that Chapter 1 (General Rules) sets out the general principles, procedures, and requirements common to all the non-book materials. Chapters 2 (Graphics and Three-dimensional Representations), 3 (Motion Pictures), and 4 (Sound Recordings) are supplementary to Chapter 1; each sets out only the special provisions necessary for the range of materials it covers, where these extend, modify, or otherwise differ from the general provisions of Chapter 1.

In only one area was the committee unable to complete its work: a chapter of special rules for the cataloging of computer records. It is hoped that attention will be given to the work of Ray Wall and to the proposals of the ALA Subcommittee on Machine Readable Records in any continuing work which the Media Cataloging Rules Committee undertakes.

While this publication is still a draft, it is one of the most carefully constructed sets of standards for the cataloging of non-book materials available, with input from the $\mathrm{Li}$ brary Association, the American Library Association, Jean Riddle Weihs and her colleagues from the Canadian Library Association, and the NCET. As such it merits careful attention by all librarians and media specialists.-Nancy L. Eaton, General Libraries, The University of Texas at Austin.

\section{Organization and Staffing of the Libraries of Columbia University. Prepared by} Booz, Allen \& Hamilton, Inc. Westport, Conn.: Redgrave Information Resources, 1973.

There seems to be a distinct inability to realize that the miasmic swale from Boston, Massachusetts to Washington, D.C. becomes more disconnected from the United States as time goes on, more fictitious, more divorced from reality. Viz., when the Association of Research Libraries (housed in Nixon Bay) chose to sponsor a study "to provide guidance for the improvement of other university libraries," presumably its eighty-odd members, it had it funded in the Columbia University Library, the least typical library, in the least typical university, in the least typical city in the country. The typical ARL library is non-major, nonprivate, non-Ivy League, non-Eastern, and non-urban. The typical library disease is malnutrition, not gout. So this study was fatally flawed from the beginning.

It describes the Columbia University libraries and their present organization, analyzes their central problem in the university, and proposes a reorganization and staffing pattern to meet the problem. It concludes with a plan for implementing the reorganization.

The description of Columbia's libraries informs us early (on pages 14-15) that the university has 16,000 students, 4,100 faculty, and 7,300 staff. "Begob!" says I, "and no wonder it is that Columbia goes broke, with one employee for each 1.5 students!" Other sources inform us that BAH left out 7,000 part-time students and neglected to mention that only 1,600 of the faculty are full-time. We are once again in the wondrous presence of the mechanical tongs of the Management Consultant Experts, who manipulate facts seen through a glass darkly and even more dimly understood. We suffered through a plethora of them on Long Island in the sixties; Westat has just hung another turkey around ARL's neck. WHEN will we give up these astringent studies, totally devoid of any sensitive knowledge of the dynamics of libraries (no matter how high-priced they are) that parade under the rubric of "management"?

With our confidence in the statistics already shattered on page 15 , we proceed through a thoroughly Army-type platitudinous instructional program about the Columbia libraries that feeds us a dreary, uninstructive recitation of its objectives and twelve graphs, maps, charts, and pie-graphs in ten pages of the worst tradition of useless graphics. We are then liberated from an exposition that could be intelligently presented in two pages, and launched into the Recommended Plan of Organization. Here, obviously, BAH should be at home.

But if they are, it doesn't pay to visit 